\title{
A new measure of international product innovation
}

\author{
Valeska V. Geldres-Weiss ${ }^{1}$, Joaquín Monreal-Pérez² ${ }^{2}$ Dirceu Tornavoi-Carvalho ${ }^{3}$, Jorge Tello-Gamarra ${ }^{4}$
}

ABSTRACT

KEY WORDS:

JEL Classification:

\begin{abstract}
It is important for firms to undertake product innovation since this will enable them to incorporate additional value to its market offer and, consequently, will increase their international competitiveness. Thus, the aim of this article is to develop a new index, the Export Product Innovation Index (EPII), a metric that associates product innovation to export activity according to the value of new export products / goods traded abroad at a single company level. The proposed index is built on official export data and based on the Harmonized System Codes. Therefore, the EPII may be widely generalized and calculated for every export firm all over the world for which export shipping data is available, enabling benchmarks for companies, international comparative studies and policy making. This article uses data on Chilean fruit exporters to illustrate EPII calculation and use. Through the comparison of this new index with some previous ones measuring product innovation overall population of Chilean fruit exporters, it is demonstrated that the EPII provides more accurate information to appraise a firm's export product innovation performance.
\end{abstract}

Product Innovation, International Competitiveness, Export Product Innovation Index, Harmonized System Codes, Fruit Exports, Chile

\section{M160, F130}

\section{Introduction}

Various theoretical frameworks address sources of value creation (Amit \& Zott, 2011). In the scope of export business, the question is: Which sources of value are of particular importance? Hence, we first measure the export product innovation through a new index.

Although recent decades have seen the emergence of innovation indexes applied to different types of innovation, levels of aggregation and sources of data, in

Correspondence concerning this article should be addressed to: Joaquín Monreal-Pérez, Murcia University, Spain. E-mail: joaquinmonreal@hotmail.com the export context there have been few studies on the elaboration of individual innovation indexes. In the literature, the most studied types of innovation refer to production, processing, management and marketing (OECD, 2005). However, when it comes to exports, product innovation allows us to capture most accurately the results of this activity. Therefore, this research will be focused on product innovation.

Why choose product innovation among the different types of innovation outputs? It is considered to be the most important kind of innovation. since it is said to be an antecedent of any firm innovation strategy of the firm. In the words of Boer and During (2001), "in most cases the main motive for starting the innovation 
process was the need to develop (a) new product(s), often driven by the demands of just one customer, or the desire to penetrate new markets by developing new products or adapting existing products" (p. 14).

Thus, the objective of this article is to develop a new index, the Export Product Innovation Index (EPII), a metric that associates product innovation to export activity according to the value of new products traded abroad by export firms over time.

The purpose of this new index (EPII) is to define a product innovation metric associated with firms' export activity. It is an approach that seeks to capture product innovation in international markets and to contribute to traditional product innovation indicators as well. Dutta, Lanvin and Wunsch-Vincent (2017) also refers to this gap, which is both conceptual and empirical, in the annual editions of the Global Innovation Index (GII): "finding metrics that capture innovation as it happens in today's world remains a key challenge, since direct official measures that quantify innovation outputs are still scarce". Thus, the present article contributes to narrowing down such gaps by focusing on product innovation from an export perspective, since most studies focus on classical indicators of innovation (e.g. R\&D investment per year, number of patents registered per year, etc.)

The EPII is proposed as a way of measuring how much export value is created by product innovations by a company, measured by its impact on total export revenues. It is not a full model with causal or enabling factors, but a performance measure based on official data, which enables us to compare individual firms, build a ranking and identify case studies for future research on the underlying factors for the EPII index level achieved. EPII is proposed in such a way that it can be calculated using existing governmental data in most countries. Moreover, the article brings empirical results which add to official statistics on the amount of innovative activity in a given sector (fruit), and country level (Chile). Chile is the leading fruit exporter in the southern hemisphere and the world's leading exporter of table grapes and blueberries. The Chilean fruit area occupies 294,000 hectares, the sector produces around 5 million tons of fruit, of which 2.6 million are exported as fresh fruit, generating more than USD 4,000 million annually. (ODEPA, 2018). Product innovation is espe- cially significant for fruit producers from Chile, who mostly sell standardized products to international intermediaries and therefore with limited profitability. Moreover, small size companies, which predominate in a country like Chile, are the type of organizations carrying out mainly product innovations (Boer \& During, 2001).

Thus, for the empirical example and analysis, we have used as our example a country with a clear exporting vocation - Chile - and a sector that is relevant for this country in its international performance -the fruit sector.

The motivations behind this research are first that innovation is important to boost economic progress and competitiveness. In the field of international business, many governments are putting export promotion and innovation at the centre of their growth strategies. Second, there is the awareness that the definition of innovation has been broadened to recognize innovation in more areas, and we seek to provide an indicator of product innovation based on export markets, which is a topic that has not been treated in the literature.

The EPII provides a key tool that uses detailed metrics based on the international definitions of the Harmonized Commodity Designation and Coding System (HS) of the World Customs Organization (WCO). The innovative activity of exporting firms enables export promotion policies to be refined.

The rest of the paper is organized as follows: section 2 reviews the literature related to innovation indexes; section 3 establishes the conceptual foundations of the proposed index; section 4 provides its formulation and an example of its calculation; section 5 offers the results and an empirical comparison with other indexes of innovation are presented; finally, section 6 gives the discussion and conclusions.

\section{Innovation Indexes}

Innovation, and in particular its measurement, has been approached from a wide number of perspectives. These belong to two groups, according to the public or private objectives that the measure seeks to achieve, and the ownership of the information. From a firm's perspective, this means setting Key Performance Indicators (KPIs), based on firm-level data, which access its innovation capabilities and results. By doing so, it handles what is considered a strategic asset, which re- 

Table 1. Top 10 journals by number of papers on Innovation Indexes and export in Science Direct

\begin{tabular}{lclc}
\hline Publication title & Articles & Publication title & Articles \\
\hline Technological Forecating and Social Change $\left.*^{*}\right)$ & 20 & Rai Revista de Administração e inovação & 6 \\
Procedia Economics and Finance & 14 & Journal of Business Research & 4 \\
Research Policy $\left(^{*}\right)$ & 11 & Journal of Cleaner Production & 3 \\
Procedia - Social and Behavioral Sciences & 10 & World Patent Information & 3 \\
Technovation $\left(^{*}\right)$ & 9 & Procedia Computer Science & 3 \\
\hline
\end{tabular}

Note: The journals also reviewed by Speroni et al. (2015) are marked with $\left(^{*}\right)$.

Thus, it considers export as an output of innovation, not an antecedent.

According to this index, exports, and only those of the high tech products, are part of the output pillar "Knowledge \& technology outputs", which encompasses three sub-pillars. To compose the "third subpillar, namely knowledge diffusion, the GII includes: (a) intellectual property receipts as a percentage of total trade; (b) high-tech net exports as a percentage of total exports; (c) exports of ICT services as a percentage of total trade; and (c) net outflows of FDI" (Dutta et al. 2017, p. 53).

Our study adopts the same perspective as the GII, considering export as an output, but not limited to high-tech products. Our literature review found a few scientific publications studying innovation in the export scenario, but none on how the indexes are elaborated. To address this gap, this article develops a new index, the Export Product Innovation Index (EPII), a metric that associates innovation to export activity by the value of new products traded abroad by exporting firms over time.

In doing so, we return to the basics, to the definition given by the Oslo Manual developed by the European Communities and the Organization for Economic Co-operation and Development (OECD): "An innovation is the implementation of a new or significantly improved product (good or service), a new process, a new marketing method, or a new organizational method in business practices, workplace organization, or external relations"(OECD, 2005, p. 146). Thus, in considering innovation, we consider not only the traditional categories of incremental and radical innovation, but innovation that change the architecture of a product without changing its components (Henderson \& Clark, 1990).

We argue that there are indirect official measures that quantify innovation outputs available that may build a metric that captures innovation outputs as they occur in the world today, and so address the gap, stated by Dutta et al. (2017), and hence, accomplish the stated objective of this article.

\section{Conceptual basis for calculating the EPII}

EPII calculation is based on the Harmonized System Code (HS Code). This index is conceptualized so as to be calculated at a single company level, based on official export data, and described by the HS Code, which is the most successful legally binding instrument of the World Customs Organization (WCO) and is a code used worldwide and consists of six digits.

\subsection{Harmonized System or HS (WCO, 2018a)}

The Harmonized Commodity Description and Coding System generally, referred to as "Harmonized System" or simply "HS", is a multipurpose international product nomenclature developed by the World Customs Organization (WCO). It comprises about 5,000 commodity groups, each identified by a six-digit code, arranged in a legal and logical structure and is supported by well-defined rules for uniform classification. 
Table 2. Sections and Chapters of HS Code

\begin{tabular}{|c|c|c|}
\hline Section & Name of Section & $\begin{array}{l}\text { Total Chapters } \\
\text { by Section }\end{array}$ \\
\hline । & LIVE ANIMALS; ANIMAL PRODUCTS & 5 \\
\hline$\|$ & VEGETABLE PRODUCTS & 9 \\
\hline III & $\begin{array}{l}\text { ANIMAL OR VEGETABLE FATS AND OILS AND THEIR CLEAVAGE PRODUCTS; PREPARED EDIBLE } \\
\text { FATS; ANIMAL OR VEGETABLE WAXES }\end{array}$ & 1 \\
\hline IV & $\begin{array}{l}\text { PREPARED FOODSTUFFS; BEVERAGES, SPIRITS AND VINEGAR; TOBACCO AND MANUFACTURED } \\
\text { TOBACCO SUBSTITUTES }\end{array}$ & 9 \\
\hline V & MINERAL PRODUCTS & 3 \\
\hline $\mathrm{Vl}$ & PRODUCTS OF THE CHEMICAL OR ALLIED INDUSTRIES & 11 \\
\hline VII & PLASTICS AND ARTICLES THEREOF; RUBBER AND ARTICLES THEREOF & 2 \\
\hline VIII & $\begin{array}{l}\text { RAW HIDES AND SKINS, LEATHER, FURSKINS AND ARTICLES THEREOF; SADDLERY AND } \\
\text { HARNESS; TRAVEL GOODS, HANDBAGS AND SIMILAR CONTAINERS; ARTICLES OF ANIMAL GUT } \\
\text { (OTHERTHAN SILK-WORM GUT) }\end{array}$ & 3 \\
\hline IX & $\begin{array}{l}\text { WOOD AND ARTICLES OF WOOD; WOOD CHARCOAL; CORK AND ARTICLES OF CORK; } \\
\text { MANUFACTURES OF STRAW, OF ESPARTO OR OF OTHER PLAITING MATERIALS; BASKETWARE } \\
\text { AND WICKERWORK }\end{array}$ & 3 \\
\hline$x$ & $\begin{array}{l}\text { PULP OF WOOD OR OF OTHER FIBROUS CELLULOSIC MATERIAL; RECOVERED (WASTE AND } \\
\text { SCRAP) PAPER OR PAPERBOARD; PAPER AND PAPERBOARD AND ARTICLES THEREOF }\end{array}$ & 3 \\
\hline$X I$ & TEXTILES AND TEXTILE ARTICLES & 14 \\
\hline XII & $\begin{array}{l}\text { FOOTWEAR, HEADGEAR, UMBRELLAS, SUN UMBRELLAS, WALKING-STICKS, SEAT-STICKS, WHIPS, } \\
\text { RIDING-CROPS AND PARTS THEREOF; PREPARED FEATHERS AND ARTICLES MADE THEREWITH; } \\
\text { ARTIFICIAL FLOWERS; ARTICLES OF HUMAN HAIR }\end{array}$ & 4 \\
\hline $\mathrm{XIII}$ & $\begin{array}{l}\text { ARTICLES OF STONE, PLASTER, CEMENT, ASBESTOS, MICA OR SIMILAR MATERIALS; CERAMIC } \\
\text { PRODUCTS; GLASS AND GLASSWARE }\end{array}$ & 3 \\
\hline $\mathrm{XIV}$ & $\begin{array}{l}\text { NATURAL OR CULTURED PEARLS, PRECIOUS OR SEMI-PRECIOUS STONES, PRECIOUS METALS, } \\
\text { METALS CLAD WITH PRECIOUS METAL AND ARTICLES THEREOF; IMITATION JEWELLERY; COIN }\end{array}$ & 1 \\
\hline$X V$ & BASE METALS AND ARTICLES OF BASE METAL & 12 \\
\hline $\mathrm{XVl}$ & $\begin{array}{l}\text { MACHINERY AND MECHANICAL APPLIANCES; ELECTRICAL EQUIPMENT; PARTS THEREOF; } \\
\text { SOUND RECORDERS AND REPRODUCERS, TELEVISION IMAGE AND SOUND RECORDERS AND } \\
\text { REPRODUCERS, AND PARTS AND ACCESSORIES OF SUCH ARTICLES }\end{array}$ & 2 \\
\hline$X V I I$ & VEHICLES, AIRCRAFT, VESSELS AND ASSOCIATED TRANSPORT EQUIPMENT & 4 \\
\hline $\mathrm{XVIII}$ & $\begin{array}{l}\text { OPTICAL, PHOTOGRAPHIC, CINEMATOGRAPHIC, MEASURING, CHECKING, PRECISION, } \\
\text { MEDICAL OR SURGICAL INSTRUMENTS AND APPARATUS; CLOCKS AND WATCHES; MUSICAL } \\
\text { INSTRUMENTS; PARTS AND ACCESSORIES THEREOF }\end{array}$ & 3 \\
\hline XIX & ARMS AND AMMUNITION; PARTS AND ACCESSORIES THEREOF & 1 \\
\hline$X X$ & MISCELLANEOUS MANUFACTURED ARTICLES & 3 \\
\hline$X X I$ & WORKS OF ART, COLLECTORS' PIECES AND ANTIQUES & 1 \\
\hline \multicolumn{2}{|c|}{ TOTAL CHAPTERS } & 97 \\
\hline
\end{tabular}

Source: Adapted from "HS Nomenclature 2017 edition" by WCO. (2018c). Available at http://www.wcoomd.org/en/topics/ nomenclature/instrument-and-tools/hs-nomenclature-2017-edition/hs-nomenclature-2017-edition.aspx 
The system is used by more than 200 countries and economies as a basis for their Customs tariffs and for the collection of international trade statistics. Over 98 $\%$ of the merchandise in international trade is classified in terms of the HS (WCO, 2018a). The HS contributes to the harmonization of Customs and trade procedures, and the non-documentary trade data interchange in connection with such procedures, thus reducing the costs related to international trade. It is also extensively used by governments, international organizations and the private sector for many other purposes such as internal taxes, trade policies, monitoring of controlled goods, rules of origin, freight tariffs, transport statistics, price monitoring, quota controls, compilation of national accounts, and economic research and analysis. The HS is thus a universal economic language and code for goods, and an indispensable tool for international trade. The Harmonized System is governed by "The International Convention on the Harmonized Commodity Description and Coding System".

The WCO published a new version of the Harmonized System on 1 January 2017, following a five-year review cycle. This new instrument allows all Customs administrations to monitor and control the goods trade, especially those having a social and environmental impact. The nature of this review also highlights the partnerships maintained by the WCO with international organizations such as the Food and Agricultural Organization of the United $\mathrm{Na}$ tions. This trend should continue as new issues are raised that require clear and appropriate responses (WCO, 2018b).

\subsection{HS Nomenclature (2017 edition) (WCO, 2018c)}

The text of the Nomenclature established under the International Convention on the Harmonized Commodity Description and Coding System, amended as at 1 January 2017. The Nomenclature includes the General Rules for the Interpretation of the Harmonized System, the Section, Chapter and Subheading Notes, and the headings and subheadings. The HS Code is organized in 21 sections, ranging from "live animals; animal products “, up to” works of art, collectors' and antiques ", categorized in 97 chapters (WCO, 2018c) (See Table 2).
Each heading is identified by four digits, the first two indicating the Chapter number and the second two the numerical order in which the heading appears within that Chapter. The heading numbers are shown in the first column. The second column contains the texts of the headings in upper case. The third column contains the number of sections of the chapter.

\section{EPII definition and calculation (EPII}

has been registered by the Chilean "Departamento de Derechos Intelectuales" under the Copyright Registration Number 295629)

The EPII is used to measure the relative weight that the introduction of new products has in the exports of a company. If the company shows EPII in the year, it means that it has done a previous job to be able to export new products, so it is innovating to cover a larger market and meet the demand that they have abroad for those products. A higher the EPII means that there is a higher percentage of exports due to the innovation of new products.

The EPII allows an appraisal of the innovative behaviour of companies over the years in relation to exports, which can be used to generate public policies, promotion programs and benchmarks for goal setting. At a more aggregate level, EPII can provide an overview of innovation export trends in the country.

The EPII may take values from $0 \%$ to $100 \%$, where $0 \%$ indicates that the company has not introduced new products in a given year, and $100 \%$ indicates that all of the exports of the company are due to the introduction of new goods.

\subsection{EPII Components}

D Product / Good = materials and/or products, which can be wholly obtained or produced, even if they are intended for later use as materials in another production process, need to be included. The terms "goods" and "products" can be used interchangeably (ASEAN definition, WCO, 2018d).

$\Delta \mathrm{FOB}=$ means the free-on-board value of the goods, including the costs of transport to the port or site of final shipment abroad. The valuation shall be made in accordance with Article VII of GATT 1994 and the Agreement on the Implementation of Article VII of GATT 1994 as contained in Annex 1A to the WTO Agreement (WCO, 2018d). 
D Harmonized System (HS) = means the Harmonized Commodity Description and Coding System (six-digit codes), including its General Rules of Interpretation, Section Notes, Chapter Notes and Subheading Notes as adopted and implemented by the Parties in their respective laws. HS are organized in chapters (two-digit codes) and headings (four-digit codes) (WCO, 2018d).

\subsection{EPII Calculation}

For an individual (specific) export company

$>$ For a year $\mathrm{t}$ :

We can identify products / goods that a company exports, measured by the number of products / goods calculated according to the number of different HS that the company exports (by their FOB value).

\section{$\rightarrow$ For a year $\mathrm{t}+1$}

We want to know if the company innovates in its products / goods portfolio. We calculate the new HS code products the company exports in $t+1$. We use the total HS with 6 digits, where the first 2 digits designate the "H.S. Chapter", the second 2 digits designate the "HS heading", and the third 2 digits designate the "HS Code" or "HS subheading". Thus, under the assumption that a firm competes in a broad sector, defined by a specific HS Chapter (such as Chapter 08 - Fruits and nuts), the export innovation is identified when the firm launches a new product / good, identified by a new 6 digits H.S. Code (for example if the firm usually exports apples, classified under HS 0808.10 and starts selling pears, classified under HS 0808.30). The interesting thing about the HS code is that it allows the scanning of all exports based on internationally recognized and standardized nomenclatures.

However, the company must not only export a new product, but also have relevant sales of that product. Then, we calculate the sales associated to the number of new HS exports in the year $t$ valued it by FOB value. Thus, we argue that there is an innovation when the company has incorporated new HS codes and has sold any quantity of them.

D The equation is the following:

\section{$\operatorname{EPII}(t)=$}

$=\frac{\text { FOB value of new } H S \text { codes of product } / \text { goods in yeart } t}{\text { Total FOB value of product } / \text { goodsin yeart }} \times 100$
EPII is the percentage change in the FOB value of new HS Code produced by the innovation in new products / goods- It is a performance measure based on official data, which enables us to compare individual firms, and rank them, and it is calculated using existing governmental data in most countries.

The calculation of the EPII for a company in a given year is defined by total sales FOB due to new products with a different H.S. Code, and by comparing these with the previous ones and dividing by overall FOB sales of the firm. The index measures the contribution that the new products / goods makes to the firm's exports. The index is calculated for each year, allowing us to measure the degree of innovation in companies, sectors and even countries over time. The EPII seeks to show the degree of innovation over time of the firms, and with this we intend to estimate the innovation profile of the firm in its export activity, and thus also analyze the creation of value of both the company and of a particular sector. The conceptual definition of "Export Product Innovation" is the Innovation due to the incorporation of a new HS code in the firm's export portfolio between one year and another.

\subsection{EPII example}

For the example we analyze a Chilean exporting company exporting fruit and its exports in 2011 and 2012. Fruit exports are classified under chapter 8 of the HS. Chapter 8, which has 68 HS codes (See Table 3).

In this example the exporting company exported during 2011 "Cranberries, bilberries and other fruits of the genus Vaccinium" under the HS code 0810.40 , and in the year 2012 continued exporting this product, but introduced other products: apples (HS code 0808.10) and cherries (HS code 0809.29). The FOB values exported for each HS code can be seen in Table 4.

Taking into account the calculation algorithm of the EPII and having the following data (See Table 2):

FOB value of new HS codes of product / goods in year $\mathrm{t}+1=353701$ US\$ FOB

Total FOB value in year $\mathrm{t}+1=2225293$ US $\$$ FOB

$$
E P I I=\frac{U S \$ 353701}{U S \$ 2225293} x 100=15,90 \%
$$

Thus, $15,90 \%$ of the company exports are due to new products. 
Table 3. Description of HS codes of Chapter 8

\begin{tabular}{|c|c|c|c|}
\hline Heading & & H.S. Code & \\
\hline \multirow{7}{*}{$\begin{array}{l}\text { Coconuts, Brazil nuts and cashew nuts, } \\
\text { fresh or dried, whether or not shelled } \\
\text { or peeled. }\end{array}$} & \multirow{7}{*}{0801} & Coconuts: Desiccated & 0801.11 \\
\hline & & Coconuts: In the inner shell (endocarp) & 0801.12 \\
\hline & & Coconuts: Other & 0801.19 \\
\hline & & Brazil nuts : In shell & 0801.21 \\
\hline & & Brazil nuts : Shelled & 0801.22 \\
\hline & & Cashew nuts : In shell & 0801.31 \\
\hline & & Cashew nuts: Shelled & 0801.32 \\
\hline \multirow{15}{*}{$\begin{array}{l}\text { Other nuts, fresh or dried, whether or } \\
\text { not shelled or peeled. }\end{array}$} & \multirow{15}{*}{0802} & Almonds: In shell & 0802.11 \\
\hline & & Almonds: Shelled & 0802.12 \\
\hline & & Hazelnuts or filberts (Corylus spp.) : In shell & 0802.21 \\
\hline & & Hazelnuts or filberts (Corylus spp.) : Shelled & 0802.22 \\
\hline & & Walnuts : In shell & 0802.31 \\
\hline & & Walnuts : Shelled & 0802.32 \\
\hline & & Chestnuts (Castanea spp.) : In shell & 0802.41 \\
\hline & & Chestnuts (Castanea spp.) : Shelled & 0802.42 \\
\hline & & Pistachios : In shell & 0802.51 \\
\hline & & Pistachios : Shelled & 0802.52 \\
\hline & & Macadamia nuts: In shell & 0802.61 \\
\hline & & Macadamia nuts : Shelled & 0802.62 \\
\hline & & Kola nuts (Cola spp.) & 0802.70 \\
\hline & & Areca nuts & 0802.80 \\
\hline & & Other & 0802.90 \\
\hline \multirow{2}{*}{$\begin{array}{l}\text { Bananas, including plantains, fresh or } \\
\text { dried. }\end{array}$} & \multirow{2}{*}{0803} & Plantains & 0803.10 \\
\hline & & Other & 0803.90 \\
\hline \multirow{5}{*}{$\begin{array}{l}\text { "Dates, figs, pineapples, avocados, } \\
\text { guavas, mangoes and } \\
\text { mangosteens, fresh or dried." }\end{array}$} & \multirow{5}{*}{0804} & Dates & 0804.10 \\
\hline & & Figs & 0804.20 \\
\hline & & Pineapples & 0804.30 \\
\hline & & Avocados & 0804.40 \\
\hline & & Guavas, mangoes and mangosteens & 0804.50 \\
\hline \multirow{7}{*}{ Citrus fruit, fresh or dried. } & \multirow{7}{*}{0805} & Oranges & 0805.10 \\
\hline & & $\begin{array}{l}\text { Mandarins (including tangerines and satsumas); } \\
\text { clementines, wilkings and similar citrus hybrids: Mandarins } \\
\text { (including tangerines and satsumas) }\end{array}$ & 0805.21 \\
\hline & & $\begin{array}{l}\text { Mandarins (including tangerines and satsumas); } \\
\text { clementines, wilkings and similar citrus hybrids: Clementines }\end{array}$ & 0805.22 \\
\hline & & $\begin{array}{l}\text { Mandarins (including tangerines and satsumas); } \\
\text { clementines, wilkings and similar citrus hybrids: Other }\end{array}$ & 0805.29 \\
\hline & & Grapefruit, including pomelos & 0805.40 \\
\hline & & $\begin{array}{l}\text { Lemons (Citrus limon, Citrus limonum) and limes (Citrus } \\
\text { aurantifolia, Citrus latifolia) }\end{array}$ & 0805.50 \\
\hline & & Other & 0805.90 \\
\hline
\end{tabular}


Table 3. Description of HS codes of Chapter 8 (Continued)

\begin{tabular}{|c|c|c|c|}
\hline Heading & & H.S. Code & \\
\hline \multirow{2}{*}{ Grapes, fresh or dried. } & \multirow{2}{*}{0806} & Fresh & 0806.10 \\
\hline & & Dried & 0806.20 \\
\hline \multirow{3}{*}{$\begin{array}{l}\text { Melons (including watermelons) and } \\
\text { papaws (papayas), fresh. }\end{array}$} & \multirow{3}{*}{0807} & Melons (including watermelons) : watermelons & 0807.11 \\
\hline & & Melons (including watermelons) : others & 0807.19 \\
\hline & & Papaws (papayas) & 0807.20 \\
\hline \multirow{3}{*}{ Apples, pears and quinces, fresh. } & \multirow{3}{*}{0808} & Apples & 0808.10 \\
\hline & & Pears & 0808.30 \\
\hline & & Quinces & 0808.40 \\
\hline \multirow{5}{*}{$\begin{array}{l}\text { Apricots, cherries, peaches (including } \\
\text { nectarines), plums and sloes, fresh. }\end{array}$} & \multirow{5}{*}{0809} & Apricots & 0809.10 \\
\hline & & Cherries: Sour cherries (Prunus cerasus) & 0809.21 \\
\hline & & Cherries: Other & 0809.29 \\
\hline & & Peaches, including nectarines & 0809.30 \\
\hline & & Plums and sloes & 0809.40 \\
\hline \multirow{8}{*}{ Other fruit, fresh. } & \multirow{8}{*}{0810} & Strawberries & 0810.10 \\
\hline & & Raspberries, blackberries, mulberries and loganberries & 0810.20 \\
\hline & & Black, white or red currants and gooseberries & 0810.30 \\
\hline & & Cranberries, bilberries and other fruits of the genus Vaccinium & 0810.40 \\
\hline & & Kiwifruit & 0810.50 \\
\hline & & Durians & 0810.60 \\
\hline & & Persimmons & 0810.70 \\
\hline & & Other & 0810.90 \\
\hline \multirow{3}{*}{$\begin{array}{l}\text { Fruit and nuts, uncooked or cooked by } \\
\text { steaming or boiling in water, frozen, } \\
\text { whether or not containing added sugar } \\
\text { or other sweetening matter. }\end{array}$} & \multirow{3}{*}{0811} & Strawberries & 0811.10 \\
\hline & & $\begin{array}{l}\text { Raspberries, blackberries, mulberries, loganberries, black, } \\
\text { white or red currants and gooseberries }\end{array}$ & 0811.20 \\
\hline & & Other & 0811.90 \\
\hline \multirow{3}{*}{$\begin{array}{l}\text { Fruit and nuts, provisionally preserved } \\
\text { (for example, by sulphur dioxide gas, } \\
\text { in brine, in sulphur water or in other } \\
\text { preservative solutions), but unsuitable in } \\
\text { that state for immediate consumption. }\end{array}$} & \multirow[b]{2}{*}{0812} & Cherries & 0812.10 \\
\hline & & Other & 0812.90 \\
\hline & \multirow{5}{*}{0813} & Apricots & 0813.10 \\
\hline \multirow{4}{*}{$\begin{array}{l}\text { Fruit, dried, other than that of } \\
\text { headings } 08.01 \text { to } 08.06 \text {; mixtures of } \\
\text { nuts or dried fruits of this Chapter. }\end{array}$} & & Prunes & 0813.20 \\
\hline & & Apples & 0813.30 \\
\hline & & Other fruit & 0813.40 \\
\hline & & Mixtures of nuts or dried fruits of this Chapter & 0813.50 \\
\hline $\begin{array}{l}\text { Peel of citrus fruit or melons (including } \\
\text { watermelons), fresh, frozen, dried or } \\
\text { provisionally preserved in brine, in } \\
\text { sulphur water or in other preservative } \\
\text { solutions. }\end{array}$ & 0814 & $\begin{array}{l}\text { Peel of citrus fruit or melons (including watermelons), fresh, } \\
\text { frozen, dried or provisionally preserved in brine, in sulphur } \\
\text { water or in other preservative solutions. }\end{array}$ & 0814.00 \\
\hline TOTAL H.S. Codes & 14 & & 68 \\
\hline
\end{tabular}

Source: Adapted from "HS Nomenclature 2017 edition" by WCO. (2018c). Available at http://www.wcoomd.org/en/topics/ nomenclature/instrument-and-tools/hs-nomenclature-2017-edition/hs-nomenclature-2017-edition.aspx 
Table 4. Example of Chilean exporting company exporting fruit (Chapter 8): Total HS codes and FOB value 2011-2012

\begin{tabular}{|c|c|c|c|c|}
\hline Chapter 8: H.S. Code & $\begin{array}{l}\text { Total HS } \\
\text { Codes } 2011\end{array}$ & FOB 2011 & $\begin{array}{c}\text { Total HS } \\
\text { Codes } 2012\end{array}$ & FOB 2012 \\
\hline Coconuts: Desiccated & 0801.11 & & 0801.11 & \\
\hline Coconuts: In the inner shell (endocarp) & 0801.12 & & 0801.12 & \\
\hline Coconuts: Other & 0801.19 & & 0801.19 & \\
\hline Brazil nuts : In shell & 0801.21 & & 0801.21 & \\
\hline Brazil nuts : Shelled & 0801.22 & & 0801.22 & \\
\hline Cashew nuts: In shell & 0801.31 & & 0801.31 & \\
\hline Cashew nuts: Shelled & 0801.32 & & 0801.32 & \\
\hline Almonds : In shell & 0802.11 & & 0802.11 & \\
\hline Almonds: Shelled & 0802.12 & & 0802.12 & \\
\hline Hazelnuts or filberts (Corylus spp.) : In shell & 0802.21 & & 0802.21 & \\
\hline Hazelnuts or filberts (Corylus spp.) : Shelled & 0802.22 & & 0802.22 & \\
\hline Walnuts : In shell & 0802.31 & & 0802.31 & \\
\hline Walnuts : Shelled & 0802.32 & & 0802.32 & \\
\hline Chestnuts (Castanea spp.) : In shell & 0802.41 & & 0802.41 & \\
\hline Chestnuts (Castanea spp.) : Shelled & 0802.42 & & 0802.42 & \\
\hline Pistachios : In shell & 0802.51 & & 0802.51 & \\
\hline Pistachios: Shelled & 0802.52 & & 0802.52 & \\
\hline Macadamia nuts: In shell & 0802.61 & & 0802.61 & \\
\hline Macadamia nuts : Shelled & 0802.62 & & 0802.62 & \\
\hline Kola nuts (Cola spp.) & 0802.70 & & 0802.70 & \\
\hline Areca nuts & 0802.80 & & 0802.80 & \\
\hline Other & 0802.90 & & 0802.90 & \\
\hline Plantains & 0803.10 & & 0803.10 & \\
\hline Other & 0803.90 & & 0803.90 & \\
\hline Dates & 0804.10 & & 0804.10 & \\
\hline Figs & 0804.20 & & 0804.20 & \\
\hline Pineapples & 0804.30 & & 0804.30 & \\
\hline Avocados & 0804.40 & & 0804.40 & \\
\hline Guavas, mangoes and mangosteens & 0804.50 & & 0804.50 & \\
\hline Oranges & 0805.10 & & 0805.10 & \\
\hline $\begin{array}{l}\text { Mandarins; clementines, wilkings and similar citrus hybrids: } \\
\text { Mandarins }\end{array}$ & 0805.21 & & 0805.21 & \\
\hline $\begin{array}{l}\text { Mandarins; clementines, wilkings and similar citrus hybrids: } \\
\text { Clementines }\end{array}$ & 0805.22 & & 0805.22 & \\
\hline $\begin{array}{l}\text { Mandarins; clementines, wilkings and similar citrus hybrids: } \\
\text { Other }\end{array}$ & 0805.29 & & 0805.29 & \\
\hline Grapefruit, including pomelos & 0805.40 & & 0805.40 & \\
\hline $\begin{array}{l}\text { Lemons (Citrus limon, Citrus limonum) and limes (Citrus } \\
\text { aurantifolia, Citrus latifolia) }\end{array}$ & 0805.50 & & 0805.50 & \\
\hline
\end{tabular}


Table 4. Example of Chilean exporting company exporting fruit (Chapter 8): Total HS codes and FOB value 2011-2012 (Continued)

\begin{tabular}{|c|c|c|c|c|}
\hline Chapter 8: H.S. Code & $\begin{array}{c}\text { Total HS } \\
\text { Codes } 2011\end{array}$ & FOB 2011 & $\begin{array}{c}\text { Total HS } \\
\text { Codes } 2012\end{array}$ & FOB 2012 \\
\hline Other & 0805.90 & & 0805.90 & \\
\hline Fresh & 0806.10 & & 0806.10 & \\
\hline Dried & 0806.20 & & 0806.20 & \\
\hline Melons (including watermelons) : watermelons & 0807.11 & & 0807.11 & \\
\hline Melons (including watermelons) : others & 0807.19 & & 0807.19 & \\
\hline Papaws (papayas) & 0807.20 & & 0807.20 & \\
\hline Apples & 0808.10 & & 0808.10 & 85803 \\
\hline Pears & 0808.30 & & 0808.30 & \\
\hline Quinces & 0808.40 & & 0808.40 & \\
\hline Apricots & 0809.10 & & 0809.10 & \\
\hline Cherries: Sour cherries (Prunus cerasus) & 0809.21 & & 0809.21 & \\
\hline Cherries: Other & 0809.29 & & 0809.29 & 267898 \\
\hline Peaches, including nectarines & 0809.30 & & 0809.30 & \\
\hline Plums and sloes & 0809.40 & & 0809.40 & \\
\hline Strawberries & 0810.10 & & 0810.10 & \\
\hline Raspberries, blackberries, mulberries and loganberries & 0810.20 & & 0810.20 & \\
\hline Black, white or red currants and gooseberries & 0810.30 & & 0810.30 & \\
\hline Cranberries, bilberries and other fruits of the genus Vaccinium & 0810.40 & 135470 & 0810.40 & 1871592 \\
\hline Kiwifruit & 0810.50 & & 0810.50 & \\
\hline Durians & 0810.60 & & 0810.60 & \\
\hline Persimmons & 0810.70 & & 0810.70 & \\
\hline Other & 0810.90 & & 0810.90 & \\
\hline Strawberries & 0811.10 & & 0811.10 & \\
\hline Raspberries, blackberries, mulberries, loganberries, black............ & 0811.20 & & 0811.20 & \\
\hline Other & 0811.90 & & 0811.90 & \\
\hline Cherries & 0812.10 & & 0812.10 & \\
\hline Other & 0812.90 & & 0812.90 & \\
\hline Apricots & 0813.10 & & 0813.10 & \\
\hline Prunes & 0813.20 & & 0813.20 & \\
\hline Apples & 0813.30 & & 0813.30 & \\
\hline Other fruit & 0813.40 & & 0813.40 & \\
\hline Mixtures of nuts or dried fruits of this Chapter & 0813.50 & & 0813.50 & \\
\hline Peel of citrus fruit or melons* & 0814.00 & & 0814.00 & \\
\hline TOTAL H.S. Codes \& FOB & 1 & 135470 & 3 & 2225293 \\
\hline
\end{tabular}

Note: *(including watermelons), fresh, frozen, dried or provisionally preserved in brine, in sulphur water or in other preservative solutions.

Source: Adapted from "HS Nomenclature 2017 edition" by WCO. (2018c). Available at http://www.wcoomd.org/en/topics/ nomenclature/instrument-and-tools/hs-nomenclature-2017-edition/hs-nomenclature-2017-edition.aspx 
Table 5. Comparison between the EPII and other indexes on Chilean product innovation performance

\begin{tabular}{|c|c|c|c|}
\hline Index & Sample & Main value & Observations \\
\hline $\begin{array}{l}\text { EPII (Export Product } \\
\text { Innovation Index) }\end{array}$ & $\begin{array}{l}\text { Firm level: } \\
249 \text { firms }\end{array}$ & 0.23 (mean value) & $\begin{array}{l}\text { Fruit Sector. } \\
2006-2015\end{array}$ \\
\hline $\begin{array}{l}\text { SIF (Survey on } \\
\text { Innovation in Firms) }\end{array}$ & $\begin{array}{l}\text { Firm level: } \\
4,940 \text { firms }\end{array}$ & $\begin{array}{l}7.87 \% \text { firms } \\
\text { performed product } \\
\text { innovations }\end{array}$ & $\begin{array}{l}\text { Official source: Ministry of Finance } \\
\text { of Chile, based on OECD and on CIS } \\
\text { (Community Innovation Survey). } \\
\text { Last four Innovation Surveys (2009-2016) }\end{array}$ \\
\hline $\begin{array}{l}\text { Gll (Global } \\
\text { Innovation Index) }\end{array}$ & Country level & $\begin{array}{l}41.2 \text { (ranking } 42 \text { out } \\
\text { of } 143 \text { countries) }\end{array}$ & Gll 2015 \\
\hline
\end{tabular}

\section{Results}

In Table 5, we describe the main value obtained with our new index, the EPII, applied to our sample of Chilean fruit exporting firms, compared to that of the SIF (Survey on Innovation in Firms) and to the one of the GII (Global Innovation Index).

As can be seen, while the EPII and the SIF are at the firm level, the GII is at the country level. The former two indexes at a micro level enable us to disentangle the firms' innovative behaviour, without considering other innovation actors included in a generic country's innovation measure, as these activities are carried out by public institutions.

Moreover, the EPII is an internationally standardized way of approaching the firm's innovative result, since it is based on the international HS codes. Its final advantage is that, thanks to its quantitative nature, the EPII allows us to measure the intensity of the obtention of product innovation outputs in a dynamic way (since it compares one year with the previous one), while other indexes, such as the SIF, have the limitation that they only point statically (in a given year) to the proportion of product innovating firms. Therefore, we argue that the EPII provides richer information.

\section{Discussion and conclusions}

The objective of this article was to develop a new index, the EPII, a metric that associates innovation to export activity by the value of new products / goods traded abroad by exporting firms. Since Chile is a largely export-oriented economy -specially the fruit sector where it is a world leader in exports-, and its firms address a deep concern of lack of added value in their products, which we argue can be solved with product innovation, we have applied the analysis to a sample of Chilean fruit manufacturers.

After explaining how the EPII is calculated (basically a measure of the exports result of new products / goods relative to total exports), we have compared this index with two other important indexes in the literature that explore innovation and that can be applied to the case of Chile: the SIF index, which can be calculated from the Survey on Innovation in Firms and the GII (Global Innovation Index). As argued in the previous section, the EPII shows three main advantages: first, since it is based on the Harmonized System codes, it can be universally applied (to almost any country, sector and performance measure); second, it is implemented at the firm level, thus allowing us to measure how competitive (in innovative terms) the firms from a specific country are; third, since it measures exactly and quantitatively the degree of the firm product innovation activity, we argue that the information provided is more ample than with other qualitative indexes that only appraise whether the firm innovates or not..

Because of all these arguments, we argue that we successfully contribute to the literature by developing a new reliable, quantitative and universalistic index that can be used to test any country's firm competitive level in terms of product innovation.

The implications of our proposal are explained below: At a public policy level, the EPII would make 
decisions regarding the allocation of public funds to improve the innovative performance of certain industrial sectors and the promotion of exports. At a company level, the EPII allows us to measure the degree of innovation in the company's export activity and its role in the firm's export performance. Thus, managers can use this measure to identify if the firm really faces a lack of innovation problem, and therefore how the firm may improve its competiveness. Additionally, the new products innovation activity (measured through the EPII) allows the firm to overcome its traditional core capabilities that may be named core rigidities since they usually limit these disruptive new projects (Leonard-Barton, 1992).

The main limitations are now detailed. First, the index algorithm is based only on one innovation final output (product innovation) and does not consider other ways of innovating (such as process, marketing, ...). Second, we focus only on one mode of entry (exports), in one country (Chile) and in one sector (fruit exports). This may limit the generalization of the results. Other industrial sectors may present results based on their own characteristics, such as the specific Regional Innovation System, their innovative culture, technological paradigms, regulatory aspects, etc. As a consequence, as future lines of research we suggest applying this research to other contexts.

Additionally, since product development is a dynamic capability that requires to involve some routines for superior performance, as a cross functional team (Eisenhardt \& Martin, 2000). In this line, Ardito and Petruzzelli (2017) analyze the role of strategic HR practices on product innovation. Consequently, further research could target not only the gathering of new products but also the study of all these complementary routines and practices.

\section{References}

Amit, R., \& Zott, C. (2001). Value creation in e-business. Strategic Management Journal, 22(6-7), 493-520.

Ardito, L., \& Petruzzelli, A. M. (2017). Breadth of external knowledge sourcing and product innovation: the moderating role of strategic human resource practices. European Management Journal, 35(2), 261-272.

Becker, W., Saisana, M., Paruolo, P., \& Vandecasteele, I. (2017). Weights and importance in composite indicators: Closing the gap. Ecological Indicators, $80,12-22$.

Boer, H., \& During, B. E. (2001). Innovation, what innovation? A comparison between product, process and organizational innovation. International Journal of Technology Management, 22(1/2/3), 83-107.

Dutta, S., Lanvin, B. \& Wunsch-Vincent, S. (Eds.). (2017). The Global Innovation Index 2017: Innovation Feeding the World (10 ${ }^{\text {th }}$ ed.). Ithaca, NY: Cornell University.

DiPietro, W. R., \& Anoruo, E. (2006). Creativity, innovation, and export performance. Journal of Policy Modeling, 28(2), 133-139.

Eisenhardt, K. M., \& Martin, J. A. (2000). Dynamic capabilities: what are they?. Strategic management journal, 21(10-11), 1105-1121.

Esteves, K., \& Feldmann, P. R. (2016). Why Brazil does not innovate: a comparison among nations. RAI Revista de Administração e Inovação, 13(10), 29-38.

Henderson, R. M., \& Clark, K. B. (1990). Architectural innovation: The reconfiguration of existing product technologies and the failure of established firms. Administrative Science Quarterly, 35(1), 9-30.

Leonard-Barton, D. (1992). Core capabilities and core rigidities: A paradox in managing new product development. Strategic Management Journal, 13, 111-125.

ODEPA. (2018). Frutas frescas [Fresh fruit]. Available at https://www.odepa.gob.cl/rubros/frutas-frescas

OECD. (2005). The Oslo manual: Guidelines for collecting and interpreting innovation data (3rd ed.). Paris: OECD.

Speroni, R. M, Dandolini, G. A., Souza, J. A. \& Gauthier, F. A. O. (2015). Estado da arte da produção científica sobre indicadores e índices de inovação [State of art of the scientific production of innovation indicators and indexes]. RAI - Revista de Administração e Inovação, 12(4), 50-75.

WCO. (2018a). What is the Harmonized System (HS)? Available at http://www.wcoomd.org/en/topics/ nomenclature/overview/what-is-the-harmonized-system.aspx

WCO. (2018b). HS Multi-Purposes Tool. Available at http://www.wcoomd.org/en/topics/nomenclature/overview/hs-multi-purposes-tool.aspx. 
WCO. (2018c). HS Nomenclature 2017 edition. Available at http://www.wcoomd.org/en/topics/ nomenclature/instrument-and-tools/hs-nomenclature-2017-edition/hs-nomenclature-2017-edition.aspx

WCO. (2018d). Definitions. Available at http://www. wcoomd.org/en/topics/origin/instrument-andtools/comparative-study-on-preferential-rulesof-origin/specific-topics/study-topics/def.aspx 